\title{
Sandviç Kumaşın Çeşitli Basma Yüklemeleri Altında Modellenmesi
}

\author{
Modeling of a Spacer Fabric Under Various Compressive Loads
}

\author{
Emrecan SOYLEMEZ ${ }^{1}$ \\ ${ }^{1}$ Marmara Üniversitesi, Mühendislik Fakültesi, Makine Mühendisliği Bölümü̈, Göztepe Kadıköy, 34722, İstanbul, Türkiye
}

Öz

Sandviç kumaş tekstil endüstrisinden geleneksel kumaşlara göre avantajlı özellikleri sayesinde kayda değer ilgi görmektedir. Sandviç kumaş çoklu iplik katmanlarının tekli iplikler ile bağlanması sonucu oluşmuştur, ve bu hava geçirgenliği yüksek sandviç yapıyı oluşturur. Buna binaen iyi termal ve nem kontrolü sağlanır. Ayrıca deri konforu da ara yüzdeki temas basıncının düzgün dağılması ile gelişmektedir. Kontak yüzeydeki yük dağılımını ve basma kuvvetine karşı sandviç kumaş davranışını anlamak önemlidir. Bu çalışma ilk olarak detaylı birim hücrenin sonlu eleman analizi (SEA) modelini açıklamaktadır. Sonrasında model sonuçlarını deney sonuçları ile kıyaslamaktadır. Buna ek olarak hiperelastik ampirik SEA modelleme yöntemi sunulmuştur, bu yöntem sayesinde tasarımcılar sandviç kumaş performansını tasarım aşamasında değerlendirebileceklerdir.

Anahtar Kelimeler: Sandviç Kumaş, Hiperelastisite, Sonlu Eleman Analiz

\begin{abstract}
Spacer fabric attracts considerable attention from textile industry due to its advantageous properties compared to conventional fabrics. It has two outer layer that is formed with multifilaments (knitted substrates), and spacer yarns (monofilaments) connect between the substrates. Therefore, it provides good thermal and humidity control. Shoes, backpacks, car seat cushions, bras and mattresses are started to get benefits of spacer fabrics to manage heat and vapor better. Also, spacer fabric is an example of a sandwich structure that provides high mechanical strength at a low specific weight. Moreover, comfort of the skin improves by distributing the contact pressure at the interface. Understanding the stress distribution at the contact and response to the compressive loading is important for the spacer fabric. This study first describes the FEA modeling of the spacer fabric in detailed unit cell. Each fiber interaction in the unit cell was included in the models. Then, the model results were compared to the experiments. The detailed model showed the fiber behavior during the compression. Besides that, hyperelastic empirical FEA model methodology was presented. With this approach, hyperelastic material properties were defined to mimic the spacer fabric reaction to the loading. By homogenizing the solid body of the spacer fabric, simulation times reduced significantly. Uniformization method is expected to allow the designers to test the spacer fabric performances in designing phase.
\end{abstract}

Keywords: Spacer Fabric, Hyperelasticity, Finite Element Analysis

\section{GİRIŞ}

Günümüzde konvansiyonel kumaşlara kıyasla sandviç kumaşlara (endüstride yaygın Türkçe kullanımı spacer kumaş olarak geçmektedir) büyük ilgi vardır. Sandviç kumaş Şekil 1'de gösterildiği gibi çoklu iplik ile örülmüş iki katman arasında tekli fiber bağlantıların kurulmasıyla oluşur. Düşük ağırlıkta yüksek mukavemet gösterebilen sandviç yapıların farklı bir uygulamasıdır. Münasip tasarım ile dokunan sandviç kumaş üzerinde uygulanan kontak basıncını düzgün şekilde dağıtarak düşürür. $\mathrm{Bu}$ sayede insan derisinin konfor seviyesi arttırılabilir. İlave olarak boşluklu yapısıyla sandviç kumaş daha iyi nefes alma, s1caklık dağılımını kontrol edebilme ve kumaştaki nemin kontrolünü sağlama imkanı verir. Böylelikle, yataklar, yastık kılıfları, ayakkabılar, sırt çantaları, araba koltukları ve sütyenler bu kumaş ile üretilmeye başlanmıştır [1]. 
Uygulama alanlarına göre farklı sandviç kumaşlar mevcuttur. Hedeflenen uygulamaya göre sandviç kumaşın istenen mekanik davranışı belirlenmelidir. Sonrasında bu mekanik özellikleri karşılayabilecek üç boyutlu yapının geometrik tasarımı, kullanılacak fiberlerin boyutları ve malzeme özellikleri tayin edilmelidir. Böylece yatakta kullanılan kalın kumaş yüksek basma kuvvetlerine dayanabilirken, daha ince ve yumuşak olan sırt çantası kumaşı daha konforlu bir temas hissi verir. Sandviç kumaşların tasarımını yaparken mekanik kuvvetlere karşı gösterdiği davranışları tahmin edebilmek, istenen ürünü kısa sürede imal edebilmek için çok önemlidir. Sandviç kumaşların basma dayanımları deneysel $[2,3]$, modelleme $[4,5]$ ve analitik $[6,7]$ olarak çalışılmıştır.

Sandviç kumaşların basma deneyleri düzgün yayılı yük etkisi görülmek için basma plakaları arasında sandviç kumaşın testleri yapılmıştır ve bu sayede kuvvet deplasman diyagramları çıkarılmıştır [4]. Sandviç kumaş ile olan etkileşimi daha iyi anlamak için küre şeklindeki metal geometrinin sandviç kumaşa basma testleri çalışılımış ve kuvvet deplasman diyagramları ile maksimum uygulanan basınç değerleri anlaşılmaya çalışılmıştır [8]. Bu çalışmaya paralel olarak kürenin bastırıldığındaki reaksiyon kuvvetin analitik olarak hesaplanması için denklemeler de türetilmiştir [6]. Farklı sandviç kumaşların basma testleri yapılarak kumaş yoğunluğu, iplik malzeme çeşidi, kumaş kalınlığı, elyaf çapı ve elyafların dağılımı gibi etkilerin basma kuvvetine olan davranışları ilişkilendirilmiştir [3]. Denekler ile yapılan çalışmada basınç sensörleri kullanılarak gerçekçi basınç dağılımının farklı sandviç kumaşlarda nasıl değiştiği ve sandviç kumaşın maksimum basınç değerlerini geleneksel kumaşlara göre düşürdüğü gözlemlenmiştir [2].

Her koşuldaki yüklemelerin deneysel çalışılmasına alternatif olarak modelleme ve analitik çalışmalar ile sandviç kumaşın tepki kuvvet mekanizmaları daha detaylı anlaşılmaya çalışılmıştır. Sandviç kumaş arasındaki tekli kıvrılmış ipliğin şekli temel alınarak analitik eğilme denklemleri çıkarılmıştır [7]. Fakat sandviç kumaş birçok farklı tekli ipliği farklı kıvrımlarda ve farklı sınır şartlarında içermektedir. Bu sebeple, basma dayanımını daha iyi anlamak için sonlu eleman analizi (SEA) çalışmaları detaylı şekilde literatürde mevcuttur. Vassiliadis vd. ipliklerin sabit şekilde dış katmanlara bağlandığı birim hücre geometrisini oluşturmuş ve basma analizlerini yapmıştır [4]. Yakın zamanda daha fazla detay içeren analizler Liu ve Hu tarafından sunulmuştur [5]. $\mathrm{Bu}$ çalışmada birim hücre modeli mikro bilgisayarlı tomografi taraması ile elde edilen verilere göre oluşturulmuştur. İlave olarak tekli ipliklerin dış katman ile olan bağlantıların farklı şekilde sınırlandırılmasının basma mekaniğine etkileri incelenmiş ve iplikler arasında basma sırasında oluşan temas kuvvetleri de hesaba katılmıştır.

Sandviç kumaşların basma karakteristiğini düzgün yayılı yük için deneysel ve nümerik çalışmalarla çıkarıldığı gözlemlenmiştir. Fakat, kullanıcı ile olan etkileşim sırasında oluşacak farklı basınç dağılımdaki yüklemelere karşı davranışlar nasıl olacak ve bu davranışların farklı tasarımlar için üretim yapılmadan nasıl sonuç verebileceğini tahmin edecek bir çalışma yazarın bilgisi dahilinde literatürde bulunmamaktadır. Bu çalışma kapsamında sandviç kumaşın basma altında hiperelastik malzeme davranışı sergilemesine dayanarak, sandviç kumaş parametrelerine bağlı olarak oluşturulan hiperelastik modeller ile deneysel basma sonuçların birbirleri ile örtüşmesi sağlanmıştır. Bu modeller referans alınarak farklı sandviç kumaşların nasıl davranacağını tahmin edebilecek modeller oluşturulabilir. İplik detaylarına ve karmaşı geometriye ihtiyaç duymadan oluşturulan modeller sayesinde düzgün olmayan yükleme senaryoları da düşük sayıdaki ağlar ile bu çalışmada modellenebilmiştir. Topoloji optimizasyon çalışmalarında [9] ve tekrarlanan yapılara sahip parçalarda [10] homojenizasyon çalışmaları yapılmaktadır. Bu sayede birim hücrelerdeki yapı detaylarının değişiklikleri bütün yapıyı nasıl etkilediği çözümlenebilmektedir. $\mathrm{Bu}$ çalışmadaki yaklaşım da homojenizasyon çalışmalarını andırmaktadır.

Bu çalışma öncelikle basitleştirilmiş birim hücre modeli ile basma modellerini oluşturmuş ve basma deneyleri sonuçları ile numune A için kıyaslamaları yapmıştır. Sonrasında hiperelastik SEA modeli oluşturmuş ve numune A, B ve C için modellerin ve deneylerin kıyaslaması gösterilmiştir.

\section{MODELLEME VE YÖNTEM}

Sunulan çalışmada 3 farklı sandviç kumaş üzerinde çalışılmıştır. Tablo 1'de numune A, B ve C olarak adlandırılan numunelerin detayları verilmiştir.

Tablo 1: Numunelerin geometrik değerleri ve iplik yoğunluğu verileri.

\begin{tabular}{lllll} 
Numune & $\begin{array}{l}\text { Sandviç Kumaş̧ Katman } \\
\text { Kalınlığı, } \boldsymbol{t} \\
(\mathbf{m m})\end{array}$ & $\begin{array}{l}\text { Kalınlığı, } \boldsymbol{l t} \boldsymbol{t} \\
(\mathbf{m m})\end{array}$ & $\begin{array}{l}\text { Tekli İplik } \\
\text { Çapı, } \boldsymbol{D} \\
(\mathbf{m m})\end{array}$ & $\begin{array}{l}\text { İplik } \\
\text { Yoğunluğu } \\
\left(/ \mathbf{c m}^{2}\right)\end{array}$ \\
\hline $\mathrm{A}$ & 10 & 1.00 & 0.24 & 0.18 \\
$\mathrm{~B}$ & 6.5 & 0.75 & 0.17 & 0.59 \\
$\mathrm{C}$ & 3.5 & 0.40 & 0.06 & 3.94
\end{tabular}

Şekil 1'de A numunesinin üst, ön ve yan görünüşünün resimleri ve mikro bilgisayarlı tomografi (CT) tarama görüntüsü sunulmuştur. Toplam sandviç kumaş kalınlığ $t$ ile, 
çoklu iplikten oluşan sınır katman kalınlığ tekli iplik çap $D$ olarak kısaltılmıştır.

\subsection{Sandviç Kumaş Basma Deneyleri}

Her bir çeşit sandviç kumaş için 3 farkl $10 \mathrm{~cm}$ x $10 \mathrm{~cm}$ yüzey alanına sahip numuneler basma testlerine maruz birakılmıştır. Deneyler Instron 5566 modeli ile tatbik edilmiştir. Deney prosedürü $15 \mathrm{~cm}$ çaptaki basma plakaları kullanılarak $12 \mathrm{~mm} / \mathrm{dk}$ hız ile yerine getirilmiştir. Şekil 2'de A numunesinin kuvvet deplasman grafiğini 3 farklı numune için farklı renkteki düz çizgiler ile göstermektedir. Bu çizgilerin birbiri üstüne örtüşmesi deney tekrarlanabilirliğine işaret etmektedir.

\subsection{Sandviç Kumaşın Basma SEA Modeli}

Sandviç kumaş yapısını tarif etmek için tekli ipliklerin üst çoklu iplik sınır katmanından alt katmana birbirini tekrarlayan yolda bağlandıkları söylenebilir. Bu sebeple SEA modelini oluştururken tekli ipliklerin farklı güzergahlara sahip olan bölgesi tanımlanmış ve bu hacim birim hücre olarak belirlenmiştir. $\mathrm{Bu}$ bölgenin düzgün yayılı yüke vereceği tepki sandviç kumaşın tamamını temsil edebilmiştir. Kumpas ile detaylı ölçümleri yapılan numune A'nın Şekil 3'de görüldüğü gibi bilgisayar destekli tasarım (BDT) modelleri oluşturulmuştur. SEA modellemede simetrik düzlemler $y-x$ ve $y-z$ belirlenerek birim hücre çeyrek model olarak Şekil 4'teki gibi tanımlanmıştır. Bu modelde çoklu iplik üst ve alt katmanı 2 boyutlu kabuk plaka olarak tanımlanmış ve tekli iplikler toplamda 8 adet olarak 1 boyutlu kiriş elemanlar olarak tanımlanmıştır. İplik malzeme polyesterdir ve iplikler arasında deformasyona bağlı olarak oluşan temas yüzey sürtünme katsayısı, $\mu, 0.28$ olarak tanımlanmıştır. Numune A'da kullanılan polyester iplik ASTM D2256-02'ye göre Instron 5566 cihazı ile çekme testine maruz kalmış ve elastik-plastik davranışı ipliklerin malzeme tanımı olarak ANSYS R18.1'de tanımlanmıştır. Young's modülü 7,248 MPa olarak hesaplanmıştır ve bu değer kabuk plaka bölgesine lineer elastik malzeme olarak atanmıştır. Çeyrek birim hücrenin 2 eksende simetrik düzlemleri modelde tanımlanmış, alt düzlem deplasmanı $y$ yönünde sıfırlanmış ve üst plakaya deplasman verilmiştir. Deplasman değiştikçe de tepki kuvvetleri hesaplanmıştır. Tekli iplikler kabuk plakaya plaka kalınlığının ortasından sabitlenmiştir. Üst plakanın alt düzlemi ve alt plakanın üst düzlemi ile tekli iplikler arasında sürtünmeli kontak ayrıca tanımlanmıştır. Oluşturulan model 21,804 düğümden oluşmuştur ve modelin çözümü Intel Xeon E3-1545m $2.90 \mathrm{GHz}$ işlemci ile 2 çekirdek çalıştırılarak yaklaşık dört dakikada çözdürülmüştür.

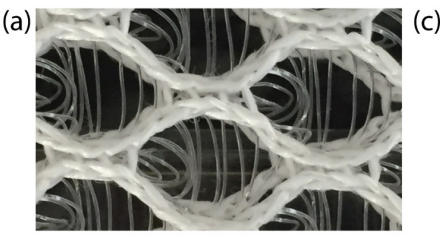

Üst Görünüş

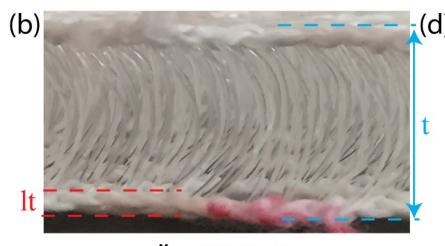

Ön Görünüş

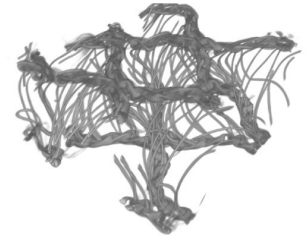

CT Tarama Görüntüsü

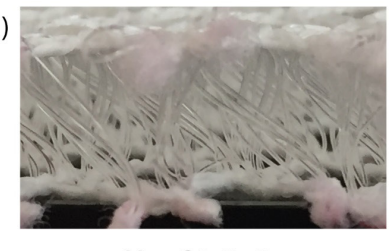

Yan Görünüş
Şekil 1: A numunesi (a) üst görünüşü, (b) ön görünüşü, (c) CT tarama görüntüsü, ve (d) yan görünüşü.

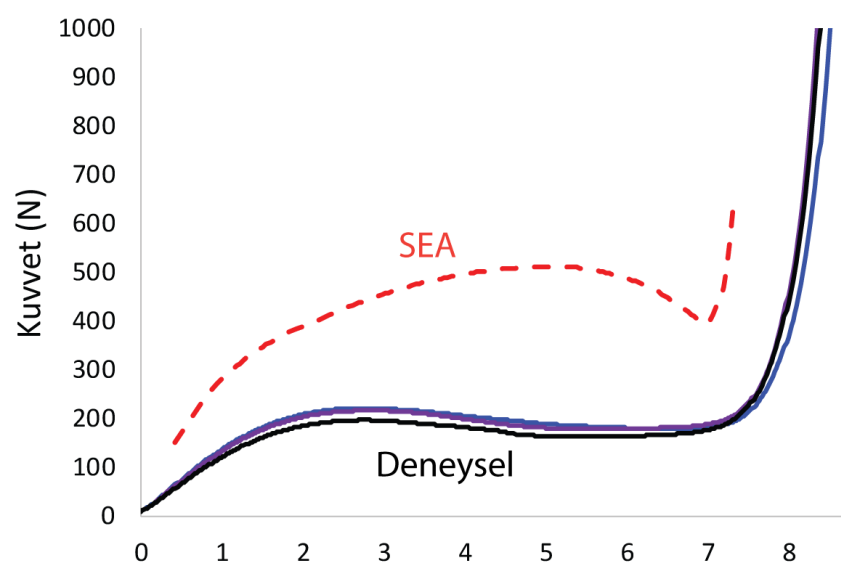

Şekil 2: Basma deneyi ve simülasyonu sonucu oluşan kuvvet deplasman grafiği. Düz çizgiler deney ve kesikli çizgiler SEA verilerini temsil etmektedir.

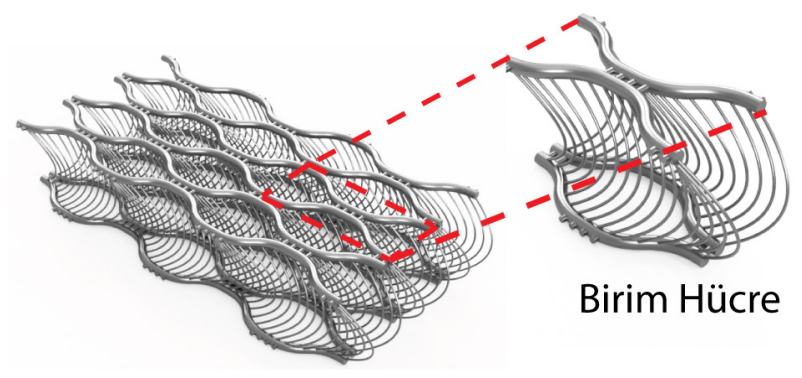

Şekil 3. Birim hücre bilgisayar 3B modeli. 
Şekil 5 modelin farklı basamaklarındaki tekli ipliklerin maksimum gerilme dağılımını göstermektedir. Şekil 5a 0.4 mm deplasman anındaki gerilme dağılımı anıdır. Bağlantı noktaları sınır koşullarından dolayı yüksek gerilime sahipken, orta bölme de kirişin en çok büküldüğü bölge olduğu için bir diğer yüksek gerilme görülen bölgedir. Şekil $5 b$ tekli fiberlerin birbirlerine temasa başlamadan önceki deplasmanın $4.5 \mathrm{~mm}$ olduğu adımdaki hallerini gösterir. Deplasman artışı ile birlikte maksimum 440 MPA gerilme değeri orta bölgede gözlenmiştir. Şekil $5 \mathrm{c}$ ise $7 \mathrm{~mm}$ deplasman olan adımın gerilme dağılımını göstermektedir. Maksimum gerilme noktaları tekli fiberlerin birbirleri ile temas ettiği noktalarda kontak mekaniğine bağlı olarak görülmektedir. Modelde verilen detayların doğru şekilde entegre oldukları bu basamaklardaki gerilme dağılımları ile onaylanmıştır.

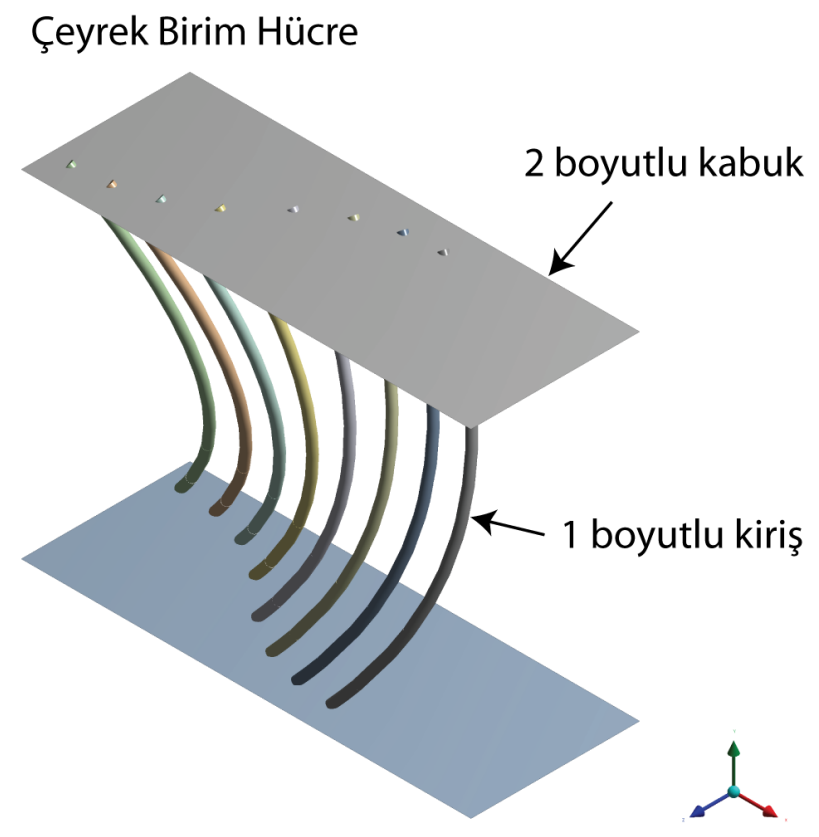

Şekil 4. SEA çeyrek birim hücre modeli.

Birim hücre SEA kuvvet deplasman grafiğini $10 \mathrm{~cm} \mathrm{x}$ $10 \mathrm{~cm}$ alana göre ölçeklendirerek karşılık gelen kuvvet sonuçları kırmızı kesikli çizgilerle Şekil 1'de gösterilmiştir. $\mathrm{Bu}$ sonuçlar $10 \mathrm{~cm}$ x $10 \mathrm{~cm}$ alana sahip numunelerin deney sonuçları ile kıyaslanmıştır. Deney ve model arasında verilen deplasmana göre ölçülen ve hesaplanan kuvvetler arasında deplasman değerine göre 3 kata kadar artan farklar gözlemlenmiştir. Bu farkın sebeplerinden biri tekli ipliklerin bölgesel farklılık gösterebileceğidir. Bu farklılık ta tepki kuvvet değerini değiştirebilir. İplik bağlantısının bazı ipliklerde serbestlik derecelerinin her eksende sıfir olmadığı bilinmektedir ve bu da modelin daha katı bir reaksiyon vermesini açıklayabilir. Yine SEA modeli yüksek deformasyonlarda rijitliğini arttırma eğiliminde olduğu için deneye kıyasla yüksek tepki kuvveti vermesi açıklanabilir. Tüm bu farklılıklara rağmen SEA modeli sandviç yapının basma kuvvetine karşı davranışını doğru bir şekilde modellemiştir. İlk başta deplasman ve kuvvet lineer bir ilişki içindeyken yaklaşı $1.5 \mathrm{~mm}$ deplasman değerinden sonra kuvvet değeri plato çizerek değer artışı ihmal edilebilir şekilde devam eder. Bu bölge ipliklerin büküldüğü mekanizmaya denk gelir. Daha sonra üst ve alt katmanların birbirine temas etmesiyle beraber de kuvvet deplasmana bağlı olarak hızlı bir artış gösterir.

a)
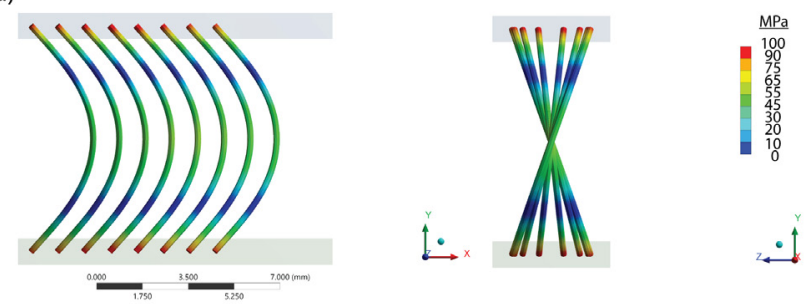

b)
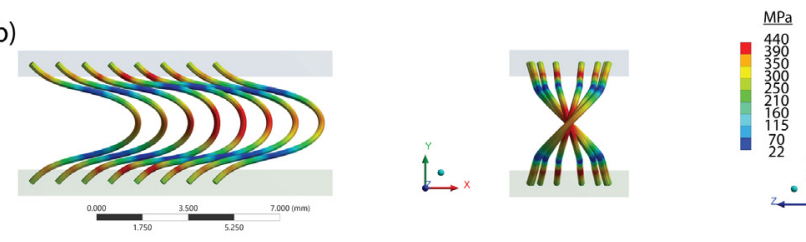

c)
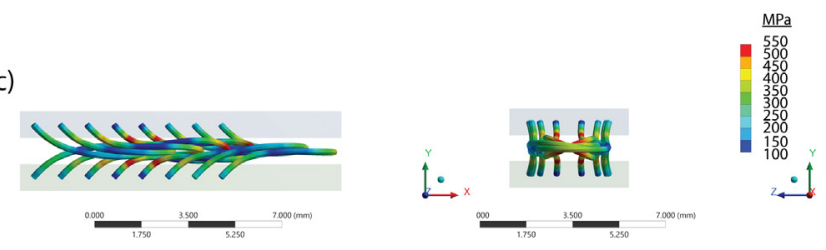

Şekil 5. A numunesi basma sonucu SEA gerilme dağ 11 ım konturlar1. (a) $0.4 \mathrm{~mm}$, (b) $4.5 \mathrm{~mm}$, ve (c) $7 \mathrm{~mm}$ deplasman an1.

\subsection{Sandviç Kumaşın Hiperelastik Malzeme Olarak Modellenmesi}

Basma yüklerine karşı elde edilen deney ve SEA model sonuçları deplasmana bağlı kuvvet diyagramları 3 farklı davranış bölgesinin birleşimi ile temsil edilebilir. Bu bölgeler başlangıç deplasmanına hızlı yükselen tepki kuvvetleri, plato bölgesinde deplasmanın artarken kuvvetin çok değişmediği kısım, ve son olarak kuvvetin tekrar ani şekilde artışa geçtiği bölgedir. Bu sandviç kumaş mekanik davranışı aynı zamanda hiperelastik malzemeyi de andırmaktadır. Bu makalede sunulan çalışma sandviç kumaş yapılarını hiperelastik malzeme olarak modellemeyi amaçlamıştır. 
Doğru davranışı tahmin edebilecek hiperelastik SEA modeli sandviç kumaş yapıların düzgün olmayan kuvvetlere karşı nasıl bir davranış göstereceğini tahmin edebilecektir. Hiperelastik modeller Poisson oran $1=0.5$ 'e yakın malzemeler için kullanılır. Sandviç kumaş malzemesi bu çalışmada polyesterdir ve $v=0.3$ hiperelastik malzeme olmadığını göstermektedir. Buna karşın hiperelastik model, özellikleri verilen sandviç kumaş yapıya karşılık gelen hiperelastik malzemeyi oluşturmayı amaçlar. Böylelikle birim hücreye kıyasla çok daha büyük bölgeler ve düzgün yayılı yüke kıyasla çok daha karmaşık kuvvetler uygulanabilir. Tasarım aşamasında imalat yapılmadan sandviç kumaş performansı hesaplanabilir. Kritik kuvvet değerleri ve kritik yükleme pozisyonları sandviç kumaş çeşidine göre tayin edilebilir. Takip eden bölüm 2.3.1 deney sonuçlarına bağlı olarak oluşturulan ampirik malzeme parametrelerinin detaylarını açıklamaktadır.

\subsubsection{Hiperelastik malzeme model parametrelerinin seçimi}

Hiperelastik malzeme modeli 3. derece Yeoh [11] modeli kullanılarak elde edilmiştir. Yeoh modeli gerinim enerjisi denklemi sunulmuştur.

$W=C_{10}\left(\overline{I_{1}}-3\right)+C_{20}\left(\overline{I_{1}}-3\right)^{2}+C_{30}\left(\overline{I_{1}}-3\right)^{2}$

Denklemde $C_{10}, C_{20}, C_{30}$ malzeme sabit katsayılarını ve $\overline{I_{1}}$ de hiperelastik model sabiti olarak tanımlanmıştır. Yüksek derece denklem ile deney sonuçlarına daha iyi yakınsayan model sonuçları elde edilebilmektedir. Yeoh modeli 3 tane sabit katsayıya bağlı olduğu için bu çalışmada ampirik katsayı tayinini kolaylaştırması açısından seçilmiştir.

SEA hiperelastik model ANSYS R18.1 kullanılarak oluşturulmuştur. Malzeme tayini $C_{10}, C_{20}$ ve $C_{30}$ katsayılarına değerler tayin edilerek oluşturulmuştur. Basma deney numuneleri ölçülerinde katı model oluşturulup Şekil 6'da görüldügü gibi, üst düzlemden deplasman verilerek kuvvet sonuçları elde edilmiştir. Model sonuçları deney sonuçlarına yakınsayana kadar sabit katsayılar iterasyon ile türetilip model koşturulmuştur. Elde edilen sabit katsayılar her bir numune için tablo 2'de gösterilmiştir.

Tablo 2: Farklı numune sandviç kumaşlar için karşılık gelen 3. Yeoh modeli sabit katsayıları.

\begin{tabular}{llll} 
Numune & $\mathbf{C}_{10}$ & $\mathbf{C}_{20}$ & $\mathbf{C}_{30}$ \\
\hline $\mathrm{A}$ & 10 & 1.00 & 0.24 \\
$\mathrm{~B}$ & 6.5 & 0.75 & 0.17 \\
$\mathrm{C}$ & 3.5 & 0.40 & 0.06
\end{tabular}

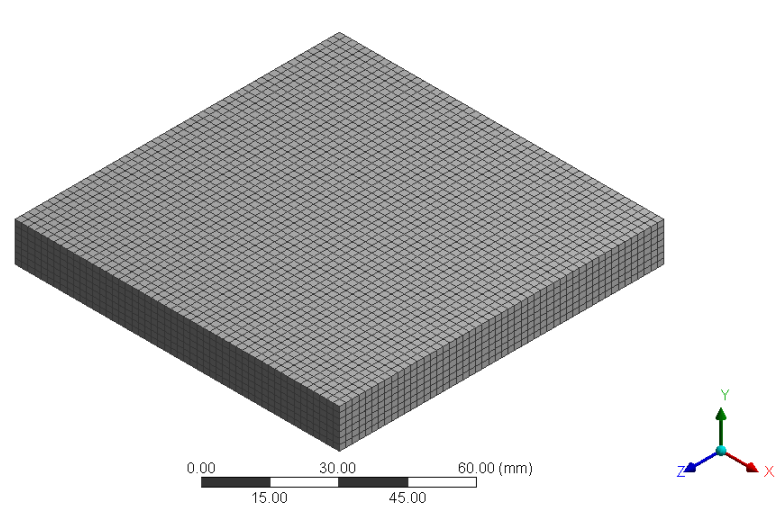

Şekil 6. Hiperelastik basma SEA modeli.

Deneylere yakınsayan model sonuçlarına ulaşabilmek için model sandviç kumaş kalınlıkları arttırılmıştır. Bu sayede elemanların yüksek deformasyonda daha rijit davranma eğilimi engellenmiştir. $\mathrm{A}, \mathrm{B}$ ve $\mathrm{C}$ numune kalınlıkları modelde sırasıyla $12.0,8.0$ ve 4.3 mm olarak alınmıştır.

\section{SONUÇLAR}

Her bir numune için basma deney sonuçları ve basma hiperelastik SEA model sonuçları Şekil 7'de gösterilmiştir. Düz çizgiler deney sonuçlarını temsil ederken, kesik çizgiler SEA model sonuçlarını temsil etmektedir. Siyah, kırmızı ve mavi çizgiler sırasıyla numune A, B ve C'nin çizimleridir. Şekil 7'de de görüldüğü gibi hiperelastik model sonuçları detaylı birim hücre SEA model sonuçlarına kıyasla deney sonuçları ile daha iyi örtüşmektedir.

$\mathrm{Bu}$ sonuçlar hiperelastik malzeme olarak tanımlanan SEA model sonuçlarının sandviç kumaş basma tepkilerini doğru bir şekilde tahmin edebileceğini göstermiştir. Sonraki adım olarak tasarım aşamasında deneyleri yapılamayan sandviç kumaş numunelerinin hiperelastik malzeme sabit katsayılarının hesaplanmasıdır.

Mevcut üç farklı numuneden elde edilen tablo 2'deki $C_{10}, C_{20}$ ve $C_{30}$ katsayıları referans değerlerdir. Bu değerleri tahmin edebilecek denklemler oluşturulmuştur ve bu sayede farklı sandviç kumaşların modellenebilmesinin önü açılmıştır. Oluşturulan denklem değişkenleri sandviç kumaşın mekanizmasının fiziğine dayandırılmıştır. Her bir iplik kiriş eğilme problemi gibi düşünülebilir. Kiriş eğilme değerleri kiriş boyunun küpüne doğrusal orantılıdır. Ayrıca alan atalet momentine de ters orantı ile ilişkilidir. Bu verilere dayanarak aşağıdaki denklem oluşturulmuştur.

$$
C_{i}=\frac{\alpha_{i} D^{4}}{m m^{4}}+\frac{\beta_{i} m m^{3}}{L^{3}}+\theta_{i} \frac{\rho c m^{2}}{100}
$$




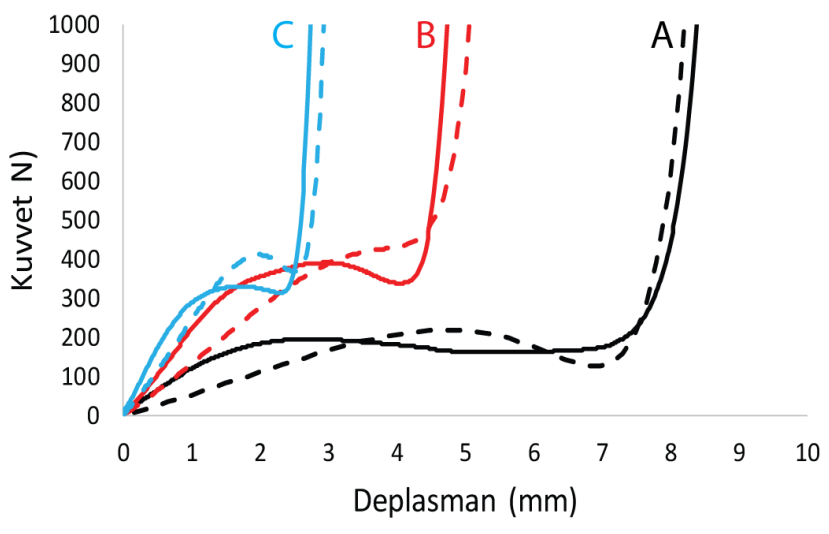

Şekil 7. Sandviç kumaş basma deney ve simülasyon sonuçları deplasmana bağlı kuvvet grafikleri. Düz çizgiler deney ve kesikli çizgiler simülasyon verilerini temsil etmektedir. A, $B$ ve $C$ numunesi verileri sırasıyla siyah, kırmızı ve mavi ile çizdirilmiştir.

Denklemde $i$ yapay değişken olarak belirtilmiştir. $D$ iplik çapı (mm), L kiriş uzunluğu $(\mathrm{mm})$ ve $\rho$ iplik yoğunluğu $\left(/ \mathrm{cm}^{2}\right)$ olarak tanımlanmıştır. $C$ sabiti birimsiz olması için denklemin farklı kısımları farklı birim çarpanları ile işleme sokulmuştur. $\alpha, \beta$, ve $\theta$ sabitleri referans değerler kullanılarak çözdürülmüştür. Tablo 3 çözüm sonucu elde edilen denklem 2'nin katsayılarını sunmaktadır. Bu değerler ile farklı iplik çapındaki, farklı iplik yoğunluğundaki ve farklı kalınlıktaki sandviç kumaşların basma modelleri için hiperelastik malzeme katsayıları denklem 2 ile tayin edilebilecektir.

Tablo 3: $C_{10}, C_{20}$, ve $C_{30}$ katsayılarını hesaplayabilmek için denklem 2'de kullanılacak $\alpha, \beta$ ve $\theta$ ampirik değerleri.

\begin{tabular}{lll}
$\boldsymbol{\alpha}_{10}$ & $\boldsymbol{\alpha}_{20}$ & $\boldsymbol{\alpha}_{30}$ \\
\hline $5.4209 \times 10^{6}$ & $-2.1954 \times 10^{6}$ & $3.9078 \times 10^{5}$ \\
$\boldsymbol{\beta}_{10}$ & $\boldsymbol{\beta}_{20}$ & $\boldsymbol{\beta}_{30}$ \\
\hline $2.3557 \times 10^{7}$ & $-8.7270 \times 10^{6}$ & $1.7076 \times 10^{6}$ \\
$\boldsymbol{\theta}_{10}$ & $\boldsymbol{\theta}_{20}$ & $\boldsymbol{\theta}_{30}$ \\
\hline$-2.9997 \times 10^{7}$ & $1.1127 \times 10^{7}$ & $-2.1842 \times 10^{6}$
\end{tabular}

Son olarak da bölüm 2.3.1'de bahsedildiği gibi model geometri kalınlıkları gerçekçi tepki kuvvetleri elde edebilmek için kalınlaştırılmıştır. Model kalınlıklarını hesaplamak için de lineer interpolasyon ile denklem 3 türetilmiştir.

$t_{m}=1.1835 t+0.2102(\mathrm{~mm})(3)$

Denklem $t_{m}$ model kalınlığını, $t$ sandviç kumaş kalınlığına göre milimetre cinsinden hesaplamaktadır.
Çalışmanın basamaklarını özetlersek, denklem 2 kullanılarak hiperelastik malzeme sabitleri hesaplanıp SEA modeline giriliyor. SEA modelindeki sandviç kumaş kalınlığı da denklem 3'e göre hesaplanıp modelde girdi olarak veriliyor. $\mathrm{Bu}$ metot sayesinde de tasarım aşamasındaki sandviç kumaşların performanslarını Şekil 7'dekine benzer doğrulukta tahmin edilmesi amaçlanmıştır.

\section{TARTIŞMA}

$\mathrm{Bu}$ çalı̧̧ma göstermiştir ki birim hücresi detaylandırılmış sandviç kumaş SEA modeli basma karakteristiğini doğru göstermesine karşın deney sonuçları ile tam olarak örtüşmemektedir. Birim hücre SEA çalışması sadece en kalın ve en düşük fiber yoğunluğuna sahip sandviç kumaş yapı (numune A) için yapılmıştır. Daha ince ve daha küçük çaptaki fiberlere sahip numunelerin modellenmesi daha da karmaşı olabilir. Bu modellerin sonuçları yüksek yoğunluktaki fiber ağının birbirleriyle daha sık etkileşim halinde olması sebebiyle deney sonuçlarına daha da uzaksayabilir.

Bu çalışmadaki alternatif modelleme metodu deney sonuçlarını esas alarak ampirik yaklaşım ile deney ile daha iyi örtüşen sonuçlar vermiştir. Deney ile örtüşen sonuçlar giriş bölümünde de bahsedilen farklı birim hücreye göre modellenmiş çalışmalar ile de elde edilebilmektedir. Fakat bu modeller düzgün yayılı yükten başka yüklemeleri modelleyememektedir. Farklı dağılmış yükler ve farklı noktalardan uygulanmış yükler bu çalışmada sunulan kapalı hacim geometriye sahip hiperelastik model ile benzetim yapılabilecektir.

$\mathrm{Bu}$ model metodu tekstil endüstrisinde sandviç kumaş tasarımı yapan mühendislerin tasarım aşamasında farklı parametre etkilerini gözlemlemelerine olanak sağlayacaktır. Örneğin araba koltuğunda maruz kalınabilecek farklı yük senaryoları etkilerini görmek için, koltuk geometrisinin modele yüklenip sandviç kumaş parametrelerine göre hiperelastik malzeme tanımı yapılıp kritik yükler gözlemlenebilir. Alternatif olarak, sandviç kumaşın dayanması gereken yüklemelerde ve istenen kalınlıklara göre nasıl bir sandviç kumaş üretilmesi gerektiği tavsiye edilebilir.

$\mathrm{Bu}$ çalışma standart sandviç kumaş malzemesi polyester için gerçekleştirilmiştir. Gelecek çalışma olarak malzeme etkilerinin de modellemeye katılması çalışılabilir. Bu sayede çalışma farklı birçok endüstriye de uygulanabilir.

\section{TEŞEKKÜR}

Instron Firması'nda yürütülen çekme ve basma deneylerindeki yardımlarından dolayı Sertan Kurt ve Alper Sakalsız'a teşekkürü bir borç bilirim. 


\section{KAYNAKLAR}

[1] Ertekin G ve Marmaral1 A 2010 Sandviç Kumaşlar Tekst. Teknol. Elektron. Derg. 4 84-98

[2] Du Z, Wu Y ve He L 2015 Determination of pressure indices to characterize the pressure-relief property of spacer fabric based on a pressure pad system Text. Res. J. 0040517515612361 -

[3] Yip J ve Ng S P 2008 Study of three-dimensional spacer fabrics:. Physical and mechanical properties J. Mater. Process. Technol. 206 359-64

[4] Vassiliadis S, Kallivretaki A, Psilla N, Provatidis C, Mecit D ve Roye A 2009 Numerical modelling of the compressional behaviour of warp-knitted spacer fabrics Fibres Text. East. Eur. 76 56-61

[5] Liu Y ve Hu H 2015 Finite element analysis of compression behaviour of 3D spacer fabric structure Int. J. Mech. Sci. 9495 244-59
[6] Du Z ve Hu H 2012 A study of spherical compression properties of knitted spacer fabrics Part I: Theoretical analysis Text. Res. J. 82 1569-78

[7] Mokhtari F, Shamshirsaz M, Latifi M ve Maroufi M 2011 Compressibility Behaviour of Warp Knitted Spacer Fabrics Based on Elastic Curved Bar Theory. J. Eng. Fabr. Fibers 6 23-33

[8] Du Z ve Hu H 2012 A study of spherical compression properties of knitted spacer fabrics Part II: comparison with experiments Text. Res. J. 82 1569-78

[9] Bendsøe M P ve Kikuchi N 1988 Generating optimal topologies in structural design using a homogenization method Comput. Methods Appl. Mech. Eng. 71 197-224

[10] Hassani B ve Hinton E 1998 A review of homogenization and topology optimization I-homogenization theory for media with periodic structure Comput. Struct. 69 707-17

[11] Yeoh O H 1993 Some Forms of the Strain Energy Function for Rubber Rubber Chem. Technol. 66 754-71 